\title{
Rosewood of Madagascar: Between democracy and conservation
}

\author{
Hery Randriamalala and Zhou Liu
}

\begin{abstract}
In 2009 an estimated 52,000 tonnes of precious wood from ca. 100,000 rosewood and ebony trees was logged in north-east Madagascar, one third originating from Marojejy National Park and its environs, the remainder from in and around Masoala National Park. At least 500,000 additional trees and many miles of vines were cut to make rafts to transport the heavy ebony and rosewood logs. Approximately 36,700 tonnes were shipped in 1,187 containers, almost all to China, for a total export sale price estimated at \$ US 220 million. In the SAVA region, members of the timber syndicate pocketed $76 \%$ of this whereas the State collected just \$ US 15.3 million. Of the three main companies that transported rosewood from Vohemar, Delmas benefited most; three banks also facilitated the illegal timber trade. Fraud is perpetrated by the syndicate and government administrators along every step in Madagascar's precious timber trade in a coordinated effort to maximize profit and minimize taxes and fines. Poor governance and a lack of clarity in forest regulation have facilitated timber trafficking and undermined judicial control; during at least three periods (1992, 2006 and 2009-2010) escalation of rosewood exportation has been facilitated by government decrees issued prior to elections or during difficult political times, in each instance accompanied by 'exceptional' government orders allowing a few powerful operators to export massive quantities of wood - all part of a carefully orchestrated cycle. The near-silence of donors and NGOs is linked to their loss of influence following suspension of all but humanitarian aid since 17 March 2009.
\end{abstract}

\section{RÉSUMÉ}

La campagne 2009 de bois précieux à Madagascar représente au minimum 52000 tonnes de bois précieux abattu, venant de 100000 arbres de bois de rose et d'ébène dont plus de 60000 situés dans les aires protégées, ce qui représente au minimum 4000 hectares de parc et 10000 hectares de forêt intacte non-classée ayant fait I'objet d'une coupe sélective. Le bois de rose provient de la région du Marojejy pour un tiers, et de celle du Masoala pour les deux autres tiers. Plus de 500000 autres arbres et des dizaines de milliers de lianes ont été coupées pour faciliter le transport du bois précieux. Environ 36700 tonnes de bois précieux ont été exportées dans 1187 conteneurs à destination de la Chine (50 tonnes d'ébène vers l'Allemagne) pour un prix de vente estimé à 220 millions

\author{
Correspondence: \\ Hery Randriamalala \\ E-mail: hery.randriamalala@gmail.com
}

de dollars, dont près de la moitié est réalisée à l'exportation au départ de Vohémar dans la SAVA. Les 22 exportateurs ont réalisé $76 \%$ de bénéfice sur ce chiffre. Le premier bénéficiaire individuel de ces exportations est l'État malgache (15,3 millions de dollars de recettes). La fraude pour l'ensemble de la filière est évaluée à 4,6 millions de dollars. Le montant des devises non rapatriées pourrait s'élever à 52 millions de dollars. Alors que la réglementation prévoyait 13 exportateurs agréés, 23 ont exporté. Des trois compagnies maritimes qui ont participé à cette activité, Delmas est celle qui en a le plus profité. Trois banques ont soutenu les exportations.

À au moins trois reprises (1992, 2006 et 2009-2010), l'exploitation du bois de rose a été facilitée par le pouvoir peu avant des élections importantes. L'impact sur les aires protégées est un amoindrissement de leur biodiversité, une fragilisation du milieu aux atteintes naturelles ou humaines. La campagne de coupe de bois de rose est en partie responsable du recul de la fréquentation touristique (-56\%) en 2009. Cette filière est un commerce inéquitable : la partie chinoise touche 25 fois plus que la partie malgache et 357 fois plus que les villageois de la forêt. Le chaos de la réglementation forestière a facilité ce trafic. La responsabilité de la classe dirigeante dans la campagne 2009 est totale. Le quasi-silence des bailleurs de fonds est la conséquence de la suspension de toute aide autre qu'humanitaire après le 17 mars 2009, ce qui leur a enlevé toute influence. Depuis l'interdiction de coupe sur le territoire chinois, en 1998, les importations de bois en provenance des pays tropicaux et tempérés ont été multipliées par six. La Chine protège donc ses propres forêts en « exportant de la déforestation ».

KEYWORDS: Illegal logging, Dalbergia, corruption, governance, China.

MOTS CLEFS : exploitation forestière illégale, Dalbergia, corruption, gouvernance, Chine.

\section{INTRODUCTION}

The oldest recorded rosewood exploitation in Madagascar dates to 1899 (Botokely 1902): Just three years after colonization, a timber trader named Mr Cayeux sourced rosewood at Ratsiharanana, south of Antalaha, and exported 50 tonnes per month, while the company Vinany Be, operating farther south on the Masoala peninsula, exported far less - a total of 200 tonnes during 1900 and 1901. 


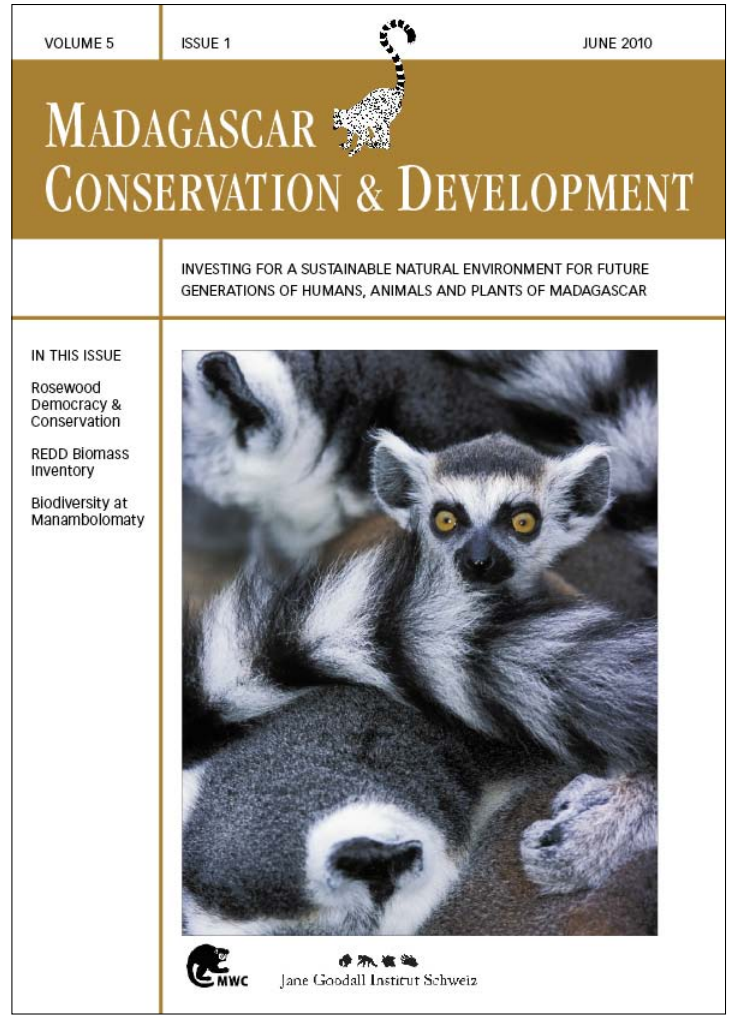

Madagascar Conservation \& Development is the journal of Madagascar Wildlife Conservation (MWC) and the Jane Goodall Institute (JGI Switzerland). It is produced under the responsibility of these institutions. The views expressed in contributions to MCD are solely those of the authors and not those of the journal editors or the publishers.

All the Issues and articles are freely available at http://www.mwc-info.net/en/services/journal.htm

\section{Contact Journal MCD}

info@journalmcd.net for general inquiries MCD funding@journalmcd.net for supporting the journal

Journal Madagascar Conservation \& Development Institute and Museum of Anthropology University of Zurich

Winterthurerstrasse 190

$\mathrm{CH}-8057$ Zurich, Switzerland

contact@mwc-info.net for general inquiries

Postfach 2701

CH-8021 Zürich, Switzerland

Logement 11, Cité Andohaniato

Antananarivo 101, Madagascar

info@janegoodall.ch for general inquiries JGI

\section{$2 \pi$ Jane Goodall Institut Schweiz}

Jane Goodall Institute Schweiz

Postfach 2807

8033 Zürich

switzerland 
Alarming and uncontrolled trade in rosewood led to the Ministry of Water and Forests (MEF; for clarity 'MEF' is used to refer to the Ministry of Water and Forests, the Ministry of Environment and Forests, and any of the other names applied at various times to this Ministry) and the Ministry of Trade to issue a decree (11932/2000) prohibiting any export of unprocessed rosewood for three years (Stasse 2002). Issued on 20 November 2000, Order No. 12704 / 2000 called for a halt to extraction of timber in all designated protected areas as well as areas on their periphery. Furthermore, according to Article 4 of this order, no exceptions were to be granted. It is estimated that up to $87 \%$ of logging of all types of wood in the eastern coastal region is illegal (Eaux et Forêts, cited by Brodbeck 1999) and that $60 \%$ of rosewood logging is illegal (Stasse 2002). Precious timber harvested in the SAVA region before 14 September 2006 was done so illegally as permits were not in accordance with applicable laws and regulations, and timber harvested thereafter is illegal under Interministerial Order No. 16030-2006 (GW and EIA 2009).

The precious timber industry is cunningly organized: International trade is frequently orchestrated by established traders holding an official export agreement or by the individuals and companies exploiting the forests. They pay independent woodcutters (i.e., local villagers or farmers) to fell trees, both within and outside officially approved lots, or in areas where the authorities have issued permits for logging companies to exploit timber and other forest products. But villagers cut trees where they are easiest to access and drag to transport points, regardless of whether they are in the delineated forest lots or outside the borders of protected areas (such as Masoala National Park), and after years of extensive exploitation, larger trees of rosewood (Dalbergia spp.) have become rare (Stasse 2002).

Working under an operating licence issued to a trader or timber company, woodcutters operate freely throughout the forest, with or without approval. Wood originating from outside designated lots is thus mixed in with legally sourced timber. The logging companies pay the collectors, who mark logs with the official forest hammer of the company, thereby legalizing the wood (Stasse 2002).

Order No. 13855 / 2001 issued by the MEF on 13 November 2001 states in Article 30, paragraph 3, that "when a tree is felled and cut into logs, the ends must be marked with a hammer or paint to indicate the locality where the tree was felled". Article 37 states that "any timber removed from a site must be cut at each end and must contain information about the forestry operator and the officials of the Forestry Administration, which will officially receive the product". According to Decree No. 98/782 of 16 September 1998, under Law 97 / 107 of 08 August 1997 (GW and EIA 2009), all products not conforming to the above regulations are considered illegal and should be confiscated.

In March 2009, the National Parks of the SAVA region were invaded by thousands of woodcutters during a period of intense, illegal logging activity that lasted at least six to eight weeks. The woodcutters removed previously cut trees and felled more trees. In north-eastern Madagascar, rosewood occurs primarily within and adjacent to Marojejy, Masoala and Mananara National Parks. Valuable timber species are under severe pressure in all these forests, regardless of whether they fall within a protected area. Frenzied felling of rosewood was observed in the north-eastern sector of Masoala National Park in 2009. The transport of logs to Antalaha was conducted openly on stretches of road both north and south of town controlled by gendarmes, a fact that reflects a serious deterioration of the law and active collaboration between the law enforcement agencies and illegal timber traders. A lack of supervision and control by the Forestry Administration over cutting, transportation and storage of rosewood is cause for grave concern (GW and EIA 2009).

The year 2009 was exceptional for the rosewood industry in Madagascar, which, between political turmoil, abundant lobbying and media campaigning, has had unprecedented international exposure. In this article we aim to analyze the rosewood industry in Madagascar in the context of patterns of political events, government decrees, and illegal logging activities. We will outline the processes and mechanisms of the rosewood trade, from the sourcing of the timber to the local and regional exporters, through shipping and exporting, to the buyers and end users of the timber.

\section{METHODOLOGY}

DATA COMPILATION. Our survey was conducted over a period of one year, starting in February 2009 as intense logging began in the protected areas of the SAVA region. Participants and observers from all sectors of the industry, alarmed by the magnitude of what was happening, provided us with documents including permits, minutes, statements and contracts, issued amongst others by officials from MEF, the Customs and Justice services, banks, shipping companies and exporters.

We conducted a survey by interviewing people involved in the exploitation and trade of rosewood, including public officers, woodcutters, port agents, travellers who visited the region, residents of the towns of Andapa, Vohemar, Sambava, Antalaha, Maroantsetra and Mananara, passengers on ships sailing between Toamasina and Antalaha, tourist guides and Madagascar National Parks (MNP) agents based at Marojejy and Masoala, tourists and journalists returning from the parks, bank employees, and two exporters based in Antalaha. For safety reasons, interviewees who have requested anonymity are quoted as 'anonymous'. Mention a company's name indicates that we are in possession of documents to support statements. Where we are not in direct possession of relevant documentation, we cite the facts, but do not list names of the individuals or companies in question.

PARAMETERS AND DEFINITIONS. The parameters used in this article are presented in Table 1. This article uses several key terms, defined as follows:

- $\quad$ Exporter (traders): Any person or company with consent (granted by the MEF) to export precious timber from Madagascar.

- $\quad$ Buyer: Any person or company buying precious timber from Madagascar. The common practice is that a buyer visits the region to meet an exporter, examine the quality of the wood, check its weight and accept the mode of payment requested by the exporter.

- Bank: A financial institution which advances funds for harvesting wood and domiciles an export operation (obligatory under Malagasy regulations as a bank must ensure that the total amount on the invoice in hard currency is repatriated within a period of three months, after which the bank has another three months to exchange $90 \%$ of the hard currency with the Central Bank). 
TABLE 1. Parameters used in calculations (partly based on GW and EIA 2009, Stasse 2002, Parant et al. 1985; rate of exchange used for Malagasy Ariary = MGA: $\$$ US1.00 = MGA 2,000)

\begin{tabular}{|c|c|c|}
\hline Parameters & Unit & Value \\
\hline \multicolumn{3}{|l|}{ Weight, length, volumes } \\
\hline External dimensions of a $20 \mathrm{Ft}$ container & $\mathrm{m}$ & $6 * 2.4 * 2.6$ \\
\hline External dimensions of a $40 \mathrm{Ft}$ container & $\mathrm{m}$ & $12.2 * 2.4 * 2.6$ \\
\hline Volume of a $20 \mathrm{Ft}$ container & $m^{3}$ & 33 \\
\hline Volume of a $40 \mathrm{Ft}$ container & $m^{3}$ & 67 \\
\hline $\begin{array}{l}\text { Maximum net weight of a } 20 \text { Ft container in Vohemar (estimation based on the limitation of the lifting equip- } \\
\text { ment at the port of Vohemar until February 2010) }\end{array}$ & tonnes & 20 \\
\hline Maximum net weight of a $20 \mathrm{Ft}$ container in Toamasina (for a wood density of ca. 1.02) & tonnes & 33 \\
\hline Maximum net weight of a $40 \mathrm{Ft}$ container in Toamasina & tonnes & 67 \\
\hline \multicolumn{3}{|l|}{ Transportation costs } \\
\hline Purchase and transportation of one ton of rosewood from the forest to Antalaha & $\$ \cup S$ & 420 \\
\hline Transportation of one container from Antalaha to Vohemar & $\$ \cup S$ & 750 \\
\hline Container packing per container & \$ US & 20 \\
\hline Dock work for one container in Vohemar & $\$ \cup S$ & 250 \\
\hline Transportation of one $20 \mathrm{Ft}$ container to Hong Kong by UAFL & $\$ \cup S$ & 1,875 \\
\hline Transportation of one 20 Ft container to Hong Kong by Delmas & $\$ \cup S$ & 2,030 \\
\hline Transportation of one $40 \mathrm{Ft}$ container to Hong Kong by Safmarine (estimation) & \$ US & 3,500 \\
\hline \multicolumn{3}{|l|}{$\underline{\text { Taxes }}$} \\
\hline Collection fee (redevance à la collecte) per kg from 28 I 2009 onwards (Interministerial order N. 003/2009) & \$ US & 0.05 \\
\hline Collection fee per kg from 21 IX 2009 onwards (Interministerial order N. 38244/2009) & $\$ \cup S$ & 0.25 \\
\hline $\begin{array}{l}\text { Exportation fee for semi crafted wood from } 2004 \text { onwards (Interministerial order N. 17939/2004) on FOB } \\
\text { price (Free On Board / Freight On Board - for a price which includes goods plus the services of loading } \\
\text { those goods onto some vehicle or vessel at a named location) }\end{array}$ & FOB price & $4.00 \%$ \\
\hline Exportation fee for crafted wood from 2004 onwards & FOB price & $1.50 \%$ \\
\hline Exportation fee for all types of wood from 21 IX 2009 onwards (Interministerial order N. 003/2009) & FOB price & $5.00 \%$ \\
\hline Fine per container from 30 July 2009 onwards (Decision N. 338/09/MEF/MI) & $\$ \cup S$ & 36,000 \\
\hline \multicolumn{3}{|l|}{ Selling price of rosewood } \\
\hline $\begin{array}{l}\text { Real selling price per kg of rosewood in logs or lumber (plaquettes); The FOB selling prices in March } 2009 \\
\text { in Vohemar varied between five and six \$ US per kg for class one timber. These prices reached \$ US } 10 \\
\text { to } 11 \text { in early 2009. The FOB price for class two wood was \$ US 3-4 per kg. To simplify calculations, we } \\
\text { considered a mean price of \$ US } 6 \text { per kg regardless of the monthly variation and classes }\end{array}$ & \$US & 6 \\
\hline \multicolumn{3}{|l|}{$\underline{B a n k s}$} \\
\hline Mean domiciliation cost per bill & \$ US & 15 \\
\hline Foreign exchange commission & & $0.50 \%$ \\
\hline \multicolumn{3}{|l|}{ Forestry } \\
\hline Mean density of rosewood & & 1.02 \\
\hline Mean density of ebony & & 1.40 \\
\hline Mean weight of a rosewood log with a diameter of $35 \mathrm{~cm}$ and a length of $2 \mathrm{~m}$ & $\mathrm{~kg}$ & 196 \\
\hline Number of logs obtained from a tree (min - max) & & $2-4$ \\
\hline Number of lumbers within a log (min - max) (Sentence N. 2617 passed on 28 July 2008 at Antalaha court) & & $3-5$ \\
\hline Number of rosewood trees per ha in protected areas (min - max) & & $3-5$ \\
\hline
\end{tabular}

- $\quad$ Shipping company: Any company that ships containers of precious wood for export from Madagascar. These companies make regular runs to Mayotte or Mauritius, where containers are gathered for shipping to their final destination.

- Tax: Charges levied on the exported precious timber. In addition to the forest fee/licence, which should indicate the quantity of wood that can be harvested in a given forest lot, the exporter must also pay a collection fee (currently \$ US $0.25 / \mathrm{kg}$ ), an export fee ( $5 \%$ of the FOB price) and a 'fine' of $\$$ US 36,000 per container (Table 1).

\section{RESULTS}

QUANTITIES. Based on our survey and the parameters listed in Table 1, we calculated the total impact of the illegal logging within the SAVA and Analanjirofo regions for the year 2009, as presented in Table 2. In addition to the estimated 100,000 trees of rosewood (Dalbergia spp.) felled in these two regions, at least 500,000 additional trees (e.g., Dombeya spp.) were also cut to make rafts to float the heavy precious timber (on average five high buoyancy trees are required to float one rosewood or ebony log) and tens of thousands of vines have been cut to bind the rafts (GW and EIA 2009). Assuming that (i) timber stored in the region of Antalaha is from the neigh- 
TABLE 2. Logging of precious timber in Madagascar during 2009.

\begin{tabular}{lccc}
\hline & Unit & Total quantity & Exportation \\
\hline Total weight & Tonnes & 52,000 & 36,730 \\
\hline Total number of logs & & 300,000 & 187,600 \\
\hline Estimated number of trees & & 100,000 & \\
\hline Estimated area impacted & ha & $4,000-10,000$ & \\
\hline Number of beams exported & & & 74,250 \\
\hline Number of containers & & 1,187 \\
\hline Selling price & \$ US & $220,000,000$ \\
\hline Taxes (\$ US 1.-- = MGA 2,000) & \$ US & $21,900,000$ \\
\hline
\end{tabular}

bouring Masoala Peninsula, and (ii) the wood stored between Sambava and Vohemar (excluding that currently stored in Vohemar awaiting export) originated from Marojejy and the banks of the Bemarivo River, we infer the following breakdown of the geographical origin of harvested timber: $64 \%$ from Masoala NP, and $36 \%$ from Marojejy NP and the Bemarivo watersheds.

The figures in Table 2 on the number of containers loaded with precious wood exported in 2009 are applicable to Vohemar and Toamasina. From March to September 2009, an average of one vessel per day left Maroantsetra and another from Mananara bound for Toamasina, accounting for the daily shipment of 50 tonnes of timber. After October 2009, the rate declined to one vessel per week, with two or three boats departing weekly from Antalaha. Stasse (2002) estimated that Toamasina has been the main port for the export of rosewood from Madagascar. A major litchi exporter shipped 300 containers of rosewood from there during this period (Toamasina port official pers comm.). Given the number of shipments observed between Antalaha and Toamasina, we deduce that the 300 containers reportedly shipped from there were of the larger 40-foot size (totalling ca. 20,000 tonnes). Of the 36,700 tonnes exported, only $249(0.7 \%)$ were of ebony and the remainder of rosewood.
The time scale diagram in Figure 1 shows monthly rosewood trade activity at the port of Vohemar as compared with the publication of government notes and orders. Activity peaked in February-March 2009, while the central government was almost completely dysfunctional (Débois 2009).

In 2000-2001 and just prior to political turmoil in 2002, rosewood exports amounted to almost 5,000 tonnes annually, declining to almost nothing for 5-6 years, and increasing again starting in 2007 (when 2,385 tonnes were shipped). Exports then escalated to almost 14,000 tonnes in 2008 (prior to the current political turmoil) and during the exceptional activity of 2009 they increased further to more than 36,000 tonnes. The figures presented for 2007 and 2008 mostly pertain to rosewood seized by the state and sold by auction to a single buyer (Anonymous 2008a). In addition, the inventory of 03 June 2009 compiled by the Forestry Administration (concerning tonnage of precious timber shipped after that date from Vohemar along with various additional reports of stocks) shows a reserve of 15,600 tonnes awaiting export.

Undoubtedly there are many additional caches of precious timber remaining concealed in forests, buried on beaches, hidden in shallow ocean waters, submerged in rivers and in rice paddies, or stashed under houses and in covered depots (Débois 2009). As we are unable to estimate the tonnage of such caches, however, we have ignored them in our analyses and our results thus offer a conservative evaluation of the current situation.

PLAYERS IN THE ROSEWOOD TRADE. Exporters: Until

September 2009, 13 exporters were involved in the rosewood trade, concentrated in Antalaha, a situation that changed significantly with the publication of Order No. 38244 / 2009 on 21 September 2009, which increased the total number of individuals or companies authorized to export precious timber to 23 between September and December 2009. This order was accompanied by noticeable encouragement for the creation of

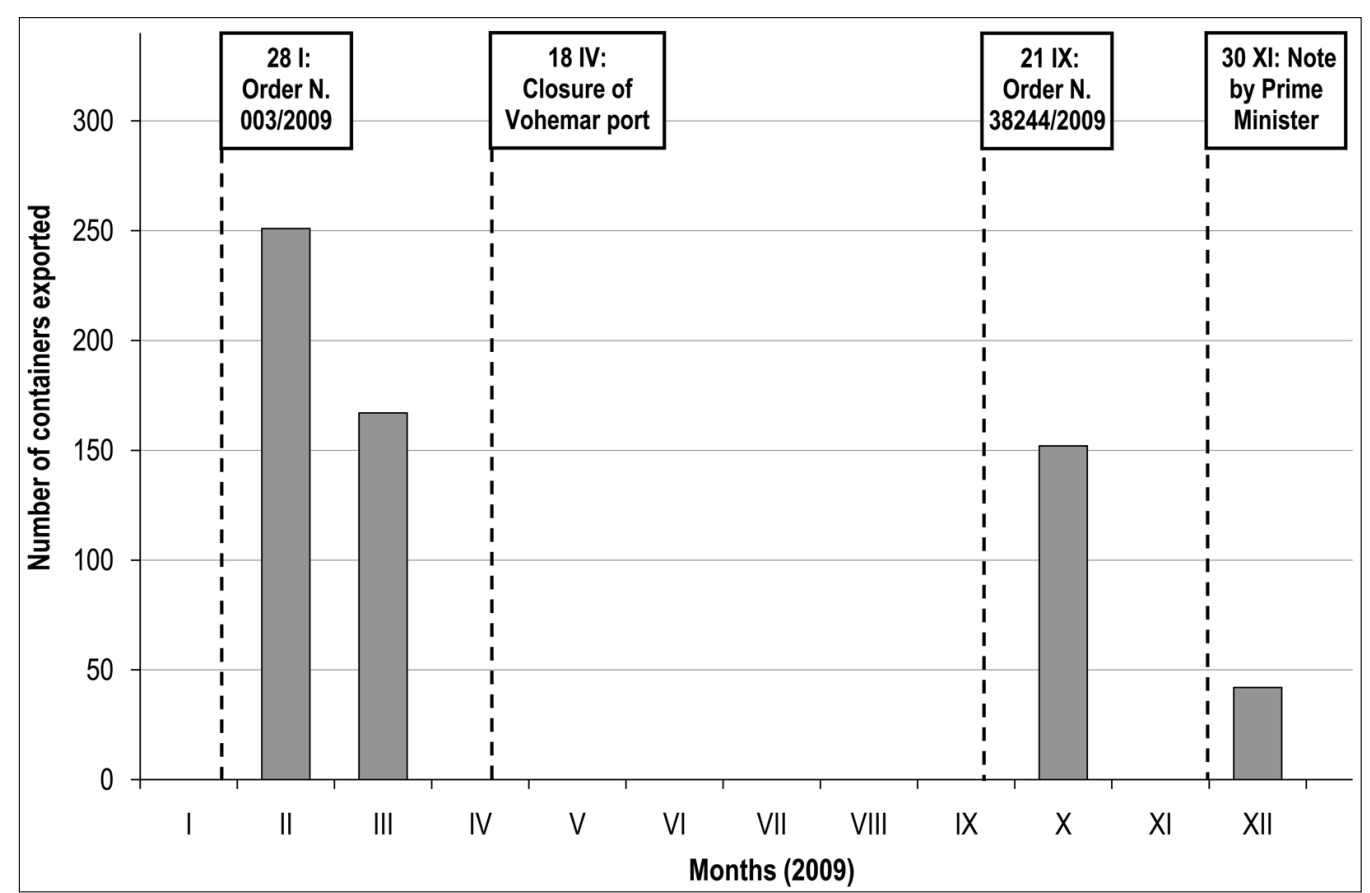

FIGURE 1. Timetable of monthly exports of precious wood from Vohemar in 2009 
new companies to export timber, not just from the SAVA region but also from the capital city of Antananarivo.

By multiplying the tonnage exported by each exporter by the estimated price received (\$ US $6 / \mathrm{kg}$ ), and then deducting taxes and miscellaneous other charges, we have attempted to estimate the profit made by the exporters. The true profit obtained by the exporters is, however, likely significantly higher that what we have estimated because it appears that in many cases Chinese buyers rather than the exporters have paid the $\$$ US 36,000 'fine' per container levied by the Administration since September 2009 (GW and EIA 2009). To put these numbers into perspective, we calculated the share received by the government (through taxes levied only in the SAVA, because those paid in Toamasina are very difficult to estimate - see below on fraud and fines) and the share going to the villagers (woodcutters and porters, estimating their number at 5,000 ). We used these figures to calculate the total revenue for the SAVA alone in 2009, which we estimated at \$ US $92,517,500$, with the state collecting a total of \$ US 15,311,000 (16.5\%), the 22 exporters operating in the region pocketing more than \$ US 70,734,000 (76.5\%, the three main exporters accounting for almost half of this, with just a little more than \$ US 15,155,000 for Ets Ranjanoro, \$ US $9,819,000$ for Ste Thunam Roger et Cie. and \$ US 8,863,000 for Laisoa Jean-Pierre) and the villagers receiving an average of just \$ US 1,300 each (or $7.0 \%$ of the total for the estimated 5,000 persons involved)

The three exporters who received the best return on their investment (i.e., net profit / gross profit) are Ets Ranjanoro (97\%), Laisoa Jean-Pierre (97\%) and Bezokiny Christian Claude (96\%). Probably because they are the most experienced companies in the business, they exported little or no timber after July 2009 the date on which the 'fines' were imposed. The three exporters who received the highest return per amount sold (profit/ $\mathrm{kg}$ exported) are Laisoa Jean-Pierre (\$ US 5.38/kg), Ets Ranjanoro (\$ US $5.35 / \mathrm{kg}$ ) and Bezokiny Christian Claude (\$ US $5.28 / \mathrm{kg}$ ). The explanation is the same as for return on investment, although Ets Ranjanoro and Laisoa Jean-Pierre employed a method that differs from that used by other traders: They exported numerous squared logs in February and March 2009, thereby reducing empty space by packing the containers more efficiently, optimizing quantity per container and thus reducing cost per volume shipped.

Banks: Three local banks have supported the export of rosewood: Bank of Africa (BOA), BNI-Crédit Lyonnais (BNI-CL), and BFV-Société Générale (BFV-SG). Note that BOA shareholders include the Agence Française de Développement (French Development Agency), the World Bank Group (through the International Finance Corporation), the Netherlands Development Finance Company, and the Banque Marocaine du Commerce Extérieur (Moroccan Bank of Foreign Trade).

Bank domiciliation: In order to control the compulsory repatriation of foreign currency to Madagascar, the Ministry of Finance requires bank certification that a local exporter has a foreign currency account in one of its branches. Certification is required for each separate transaction. Before wood can be shipped, exporters thus must pay for logging, transport and storage, and the banks provide them with necessary financial resources for this. Transactions with the 23 currently authorized exporters enabled the three banks to make profits of no less than the following amounts: BOA (ca. \$ US 98,000), BNI-CL (\$ US 32,000) and BFV-SG (\$ US 22,000).
Shipping companies: The difficulties of land transport on and around the Masoala Peninsula, due to poor or nonexistent roads, stimulated domestic shipping by water as a means of moving harvested rosewood. The timber cut in the Mananara National Park and in Makira Natural Park, as well as in the southern part of Masoala, is primarily transported by boat to Toamasina, occasionally to Antalaha. Wood from the northern sector of Masoala is usually moved along trails to Antalaha, or sometimes by ship to Toamasina. Timber extracted from Marojejy is consistently transported by road to the ports of Vohemar or Antsiranana.

Three international shipping companies have transported containers of rosewood from three ports to Asia, as follows: (1) from Vohemar: UAFL and its subsidiary Spanfreight, Delmas (a subsidiary of the CMA-CGM group), and Safmarine; (2) from Toamasina: Delmas, Safmarine, and PIL Shipping; and (3) from Antsiranana: Delmas, Safmarine and MSC. Only UAFL, Safmarine and Delmas transported precious wood in 2009 from Vohemar. Based on the parameters indicated in Table 1, these companies had the following share (number of containers $\times$ fee per container): Delmas (ca. \$ US 1,285,000), UAFL (ca. \$ US 220,000) and Safmarine (ca. \$ US 120,000).

Safmarine transported 32 40-foot containers in February and March 2009 from Toamasina (Safmarine to Schuurman In litt.), but the following month they elected to stop all shipment of precious timber from Madagascar for an indefinite period. UAFL was made aware in October 2009 of the origin and legally dubious nature of the timber they were transporting, as well as the environmental damage that the illicit logging industry causes (UAFL to Schuurman In litt.). They voluntarily stopped transporting rosewood after a final shipment on 30 October 2009 on board the Mauritius.

Buyers: In 2001, $98 \%$ of precious timber exported from Madagascar went to China (Stasse 2002), and in 2009 the figure was almost $100 \%$, the sole exception being a small quantity of ebony sent to Germany and Mauritius. In 2005 China imported a total of 29.4 million $\mathrm{m}^{3}$ of timber as logs, ca. two thirds of which originated from Siberia and $25 \%\left(7.4\right.$ million $\mathrm{m}^{3}$ ) from tropical forests (Canby et al. 2008). Most of this wood is used for manufacturing furniture that is exported to developed countries. Until 2008, Cameroon, Equatorial Guinea, Gabon and the Republic of Congo accounted for $14 \%$ of Chinese imports of raw timber (Naidu et al. 2008), with significantly less originating from Madagascar.

Chinese customs regulations utilise various classification codes for different forms or types of timber: 44039930 (logs), 94035010 (bedroom furniture) and 94036010 (other furniture). Rosewood trimmed into beams is declared under a different code, but is often mixed in with the other types of timber. For example, under the code for logs imported from Madagascar, Chinese customs lists 4,000 tonnes per year during 2000-2002, 3,000 tonnes in 2004, 4,000 tonnes in $2005,8,000$ tonnes in 2006 , no imports in 2007, and 1,000 tonnes in 2008 (James Hewitt In litt.), far less than the amounts known to be exported from Madagascar.

FOREST REGULATION. Many observers have already described the disjointed development of forest regulation in Madagascar (see Ballet and Rahaga 2009, GW and EIA 2009). Even the exporters complain that constantly changing regulations constitute a series of red and green lights. Figure 2 provides a graphic representation of regulation from 1974 to 2009. 

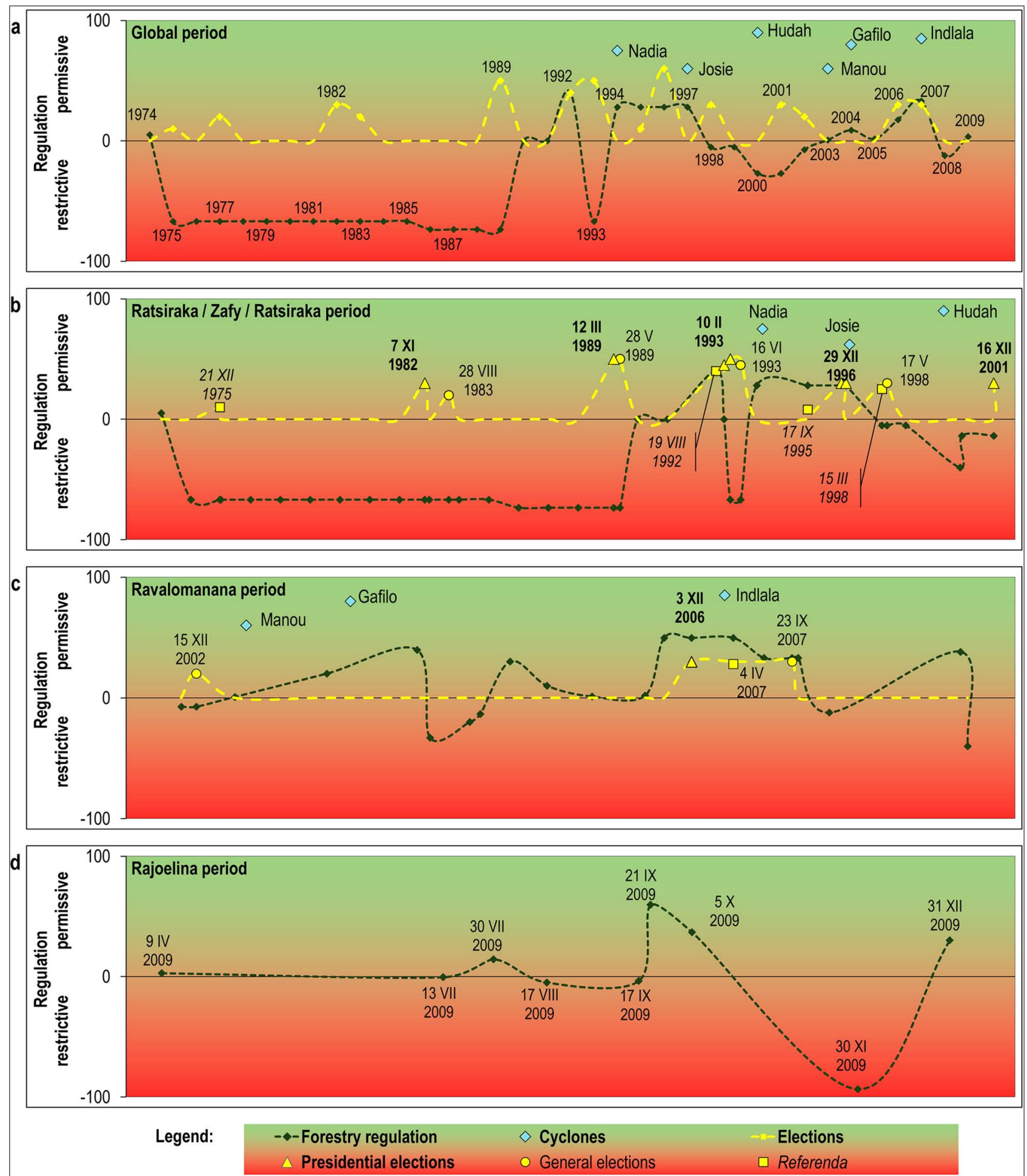

FIGURE 2. Progression of forestry regulation and political events from 1974 to 2009 (a), during Ratsiraka (1974-1993 \& 1996-2002) and Zafy periods (19931996) (b), during Ravalomanana period (c) and during Rajoelina period (d), with major cyclones shown from 1994 onwards. (Forestry regulation have been calculated by applying indices to strength of legal texts - from $8=$ Ordinance to $1=$ communiqué; applicability, clarity and functional extent of these legal texts - from $4=$ remarkable to $1=$ weak; wood targeted - rosewood and ebony $=5$, palissandre $=1$; precious wood harvesting - forbidden $=-5$, fixed quota $=1$, allowed $=5$; transportation of precious wood - forbidden $=-10$, fixed quota $=1$, allowed $=10$; exportation of precious wood - forbidden $=-20$, fixed quota $=15$, limited to a single type $=10$, allowed $=20$; taxes - generated $=-1$, increased $=-2$; these indices have been standardized between $100-$ anything allowed in the forest, and -100 - everything is forbidden in the forest. Cyclones have been shown on the graphics, graded by intensity - Very Intense Tropical, Intense Tropical and Tropical (Service de la Météorologie 2000, World Meteorological Organization 2008). Elections have been differentiated and graded - presidential, general or referendum (African Elections Database 2010).

\section{DISCUSSION}

Fraud has taken place along every step in the rosewood trade. Below we first discuss how the traders circumvent government taxation. We then analyze possible forces behind the trade, and conclude with commentary on the socio-economic impact and ecological consequences of the illegal rosewood trade.

REDUCING OR AVOIDING TAXATION. Origin of wood: Cyclones regularly strike Madagascar, and these natural disasters can impact the economy of affected areas. The Government has 
on several occasions honoured requests from timber traders to recover trees felled by cyclones for export (e.g., Interministerial Order No. 11832 / 2000 following Cyclone Hudah in April 2002). However, field investigations have shown that the majority of trees exported following the passage of a cyclone had not been uprooted by this hurricane but rather were intentionally felled (Stasse 2002, GW and EIA 2009). The United Nations (Joint UNEP / OCHA Environmental Team 2007, cited by GW and EIA 2009) and Birkinshaw and Randrianjanahary (2007) showed that hurricanes have had little effect on trees at Masoala, especially on large, long-lived individuals that are resilient and have survived many severe cyclones. A concrete example of how false information in this regard has been used involves the company Betsiaroana Jean Galbert, who sourced a large amount of rosewood in a concession near Ambohitralalana, Masoala, under license number 842 / MEF / SG / DGEF / DIREF.201 / C.04/02/03 dated 8 August 2000, which expired on 14 August 2003. The technical minutes included in the final post-logging report (No 12 / MINENVEF / CIREEF. 202 / Col dated 26 May 2006) state “(...) after successive hurricanes tearing into the concession, we noted that the following trees have been uprooted: 28 hazinina, (...), 243 Rosewood, 23 bois d ébène (ebony), 39 Nanto [for a total of 420 trees]". According to these numbers, the company claims that cyclones apparently felled mostly rosewood trees but these figures seem totally unrealistic as Dalbergia are certainly among the most cyclone-resistant trees in Madagascar and their natural population density is far less than the $58 \%$ reported here for uprooted trees.

A decade ago more than $60 \%$ of rosewood was taken from national parks, and operational documentation such as logging permits, transportation manifests, storage records and export documentation does not comply with applicable laws (Stasse 2002). Our current estimate that $64 \%$ of wood exported in 2009 is sourced from Masoala and $36 \%$ from Marojejy clearly shows that a majority of wood is now being illegally extracted from Masoala.

Weight issue: Stasse (2002: 8) indicated "When loggers perform weighing - with or without the exporter present - they report the number of logs and the tonnage, accounting for the whole lot. At the port during loading, customs check the number of logs, but not the tonnage declared. The number of tonnes is often undervalued to reduce accrued liabilities, the latter being applied to the tonnage shipped." The port of Vohemar does not have a weighbridge capable of weighing single logs or a container. Customs officials therefore rely on exporter declarations to calculate the weight of a container, which is obtained by summing up the weight of logs reported by the exporters using scales on their own premises. Interestingly, all cargo manifests from Vohemar list logs with the exactly same weight, $200 \mathrm{~kg}$ per log. Basing our calculations on a maximum weight of 20 tonnes per container (Table 1), and taking into account the tax increase from \$ US 0.05 to \$ US 0.25 / kg effective from 21 September 2009, irregularities on the collection of fees are estimated to total as much as $\$$ US 186,000. It is possible that our calculations based on the size of the logs are not fully accurate if the weights declared on the cargo manifests are also false (and therefore undervalued), in which case tax evasion is taking place rather than 'forest fraud'.

Another error has been found systematically in all documentation stating the amount to be charged for export. These forms list an estimate of volume, to which the taxes will be applied, taken from the declared weight on customs forms. Remarkably, these errors, which average \$ US 15 per tonne for rosewood, are always in favour of the exporter. The total amount of fraud during 2009 for the known amounts exported can therefore be estimated at about \$ US 550,000 (Table 2).

Smuggling: Stasse (2002) estimated that $40 \%$ of the volume exported at that time was smuggled out of Madagascar. In 2009, apart from the 12 containers seized on the Lea in October, the only evidence that we have found of smuggling is as follows: A reference to the shipment of 15 containers without documents in March 2009 from Vohemar (Andriatahina and Rakotondrabe 2009), and a survey by Missouri Botanical Garden (2009) reporting that between 03 February 2009 and 28 March 2009, 469 containers left the country without being reported (and therefore were not included in the total exports listed in Table 2). As we are not in a position to substantiate these figures due to the secretive nature of smuggling, the numbers in Table 2 must be regarded as the only reliable data currently available, providing a conservative estimate.

Repatriation of foreign currencies: Export of rosewood from Madagascar can only be carried out with permission from the Government. The official FOB price, set by the Government at $€ 2,000 / \mathrm{m}^{3}$, is used to calculate the exportation fee (Table 1). The repatriation of foreign currencies imposed by the Government applies to the total amount of the invoice. The FOB prices we found on invoices from exporters in our possession are uniformly close to this amount. We know (see paragraph on settings) that while the actual price received for rosewood is usually around $\$$ US 6 per kilogram (i.e., \$ US 6,120/ $\mathrm{m}^{3}$, Table $1)$, it can sometimes reach $\$$ US $11 / \mathrm{kg}\left(\$\right.$ US $\left.11,220 / \mathrm{m}^{3}\right)$. The lower price systematically indicated on invoices is thus used to reduce the amount of foreign currency that must be repatriated. Indeed, the bank stamps the invoice for each shipment issued the clearance and therefore must ensure that the total amount indicated in hard currency is returned to its accounts at the end of the export operation. The more an invoice is undervalued, the lower the amount of currency that must be repatriated to Madagascar and then sold to the Central Bank (90\% of the total). Even in the unlikely event that the average price received did not exceed \$ US $6 / \mathrm{kg}$, the total amount of foreign currency generated by rosewood sales in 2009 exceeded the amount required for repatriation by least \$ US 52 million. By understating the weight reported for the calculation of export duties, the total amount on the invoice is reduced and consequently the amount to be repatriated is also reduced. Fraud thus adds up.

Fraud on fines: Interministerial order No. 38244 / 209 was signed on 21 September 2009 (Figure 1) to establish a compulsory payment prior to export of $\$$ US 36,000 per contested container held in the port of Vohemar. This requirement could be regarded as a fine for the export of precious timber. This fine is then transferred to a reforestation fund that, however, has no legal basis. The enactment of this order points to a possible diversion of public funds at the highest levels of the State (GTZ 2009 In litt.).

Under this new system, exporters must pay \$ US 36,000 per container, precluding the possibility of fraud based on weight or price. However, the order opens a new loophole since it does not specify the capacity of a container, which differs by at least 12.6 tonnes between Vohemar and Toamasina 
(Table 1). This may partly explain why large quantities of wood have been transported by boat from Antalaha to Toamasina, where export is more profitable because the port is able to accommodate heavier containers. An exporter from Antalaha went so far as to sell his 'rights' to export 25 containers, as conferred by the order of 21 September, giving the exporter in Toamasina the ability to ship an additional 1,131.5 tonnes of wood. Moreover, the Toamasina-based exporter in question is reported to pay just \$ US 5,000 per container rather than the officially required $\$$ US 36,000 (Anonymous 2009). In another example of fraud, two exporters each shipped 43 containers on the Lea on 4 October 2009, well after the new fiscal measures took effect on 21 September 2009, but their export fees were dated from April at the previous, lower rate, a difference of \$ US 1.75 million. The case was tried in a Toamasina court on 11 November 2009 but we are not aware of the details of the decision.

INTERNAL AND EXTERNAL FORCES. The MEF and MNP were

overwhelmed by the events described in the Introduction. In response, a new entity was established by the Ministry in September 2009 to overcome these problems, the Task Force. In order to appreciate the role of this Task Force, it is first necessary to review the history of forest legislation in Madagascar.

The development of forest legislation and regulation in Madagascar: Figure 2 shows major trends in the development of forest regulation and confirms the impression of a succession of 'green lights and red lights', which can best be understood in relation to the terms of each of the country's presidents.

The period from 1974 to 1989 (Figure 2b) shows high stability in forest legislation and its application. Forests were closed to loggers and there was little or no felling of trees. During this period of revolutionary dictatorship, rosewood export was low and irregular. The Soviets created a few isolated airfields, such as at Doany near Andapa, and transported a limited number of logs by air. Two interesting coincidences can be noted: In November 1992 the relaxation of legislation regulating the export of precious timber immediately preceded presidential elections held on 25 November and general elections the following June; the easing of regulatory legislation again on 30 October 2000, prohibiting logging in the forests except on the outskirts of Antalaha, where the cyclone Hudah struck in April 2000.

Figure $2 \mathrm{c}$ corresponds to the Ravalomanana presidency. During this period forests were opened to exploitation on several occasions: In September 2004 after Cyclone Gafilo the preceding March; on 14 September 2006, preceding the presidential elections held on 03 December of that year; and just prior to a referendum held on April 2007. The destructive effect of the interministerial decree issued on 28 January 2009 (authorizing export under so-called 'exceptional' circumstances for thirteen registered exporters) is also evident in Figure 2c. This situation was not improved by the 18 February note prohibiting the transportation and export of ebony and rosewood until an inventory of the total number of logs was completed, as political turmoil was reaching a peak.

Figure $2 d$, which corresponds to be period during which Rajoelina came to power, clearly shows a 'sawtooth effect' in the impact of regulations. The decision taken on 30 July 2009 authorizing the export of 25 containers of rosewood for each of the 13 operators recognised by Decree 003-2009 against payment of \$ US 36,000 per container, followed by the decree of 21 Septem- ber 2009 confirming permission to export of 25 containers of ebony and rosewood for each of the same traders, again with the payment of $\$$ US 36,000 per container, was abruptly halted by Prime Minister Eugène Régis Mangalaza on 30 November 2009 in a new order prohibiting the sourcing, transport and trade of precious timber.

His successor, Prime Minister Albert Camille Vital, swiftly changed the regulations to allow for logging once again. On 31 December 2009, he issued a note with the same terms as the 21 September decree, but this time there was no deadline. According to our calculations, exports under this Order that have been reported to the State are worth \$ US 13.65 million. In addition, there are still 200 containers awaiting shipping from Vohemar, but shipping companies have been reluctant to transport wood from Madagascar following international pressure and condemnation of the illegal logging. Taxes on the wood held up in Vohemar potentially come to \$ US 9.3 million, bringing the total to almost \$ US 23 million. However, the Deputy Prime Minister, Madame Cécile Manorohanta, declared on 18 December 2009 that the elections announced by the President of Madagascar s transition government and scheduled for 20 March 2010 would cost nearly \$ US 15 million (Maka 2009).

It is obvious that on at least three occasions (November 1992, 14 September 2006, and 31 December 2009) restrictions on the trade of rosewood were relaxed just prior to important elections, when funds would be needed and it would be advantageous not to offend voters in the regions where wood is exploited. This predictable, regular pattern strongly suggests that the sale of rosewood is being used to finance Madagascar's 'democracy'. It would be interesting to investigate the reasons behind the closing of forests to logging following elections. such an investigation would need to include an analysis of the links between forest protection and the allocation of donor support for conservation projects.

The Madagascar judiciary: In the context of Madagascar's constantly changing and frequently contradictory legislative and regulatory environment, the judiciary system is at great pains to apply the law. The hierarchy (slightly simplified) of official documents in Madagascar is as follows: Constitution, law, ordinance, decree, inter-ministerial order, order, note or decision, memorandum, communiqué. Yet the widely accepted principle that lower level documents can not contradict higher level orders is frequently violated in Madagascar. Two examples:

- Interministerial Order No. 003 / 2009 of 28 January 2009 [Figure 1] stipulates in Article 6: "The liquidation of the stocks (...), shall be completed no later than 30 April 2009. After this period, no exemption will be granted $(\ldots)^{\prime \prime}$, yet Decision No. 338 / 09 / MEF / MI of 30 July 2009 states the opposite: "An export quota of 25 containers of rosewood is assigned to each of the 13 operators in the ministerial decree No. 003-2009 (...)".

- Interministerial Order No. 38244 / 2009 of 21 September 2009 [Figure 1] requires in Article 14 that "(...) the liquidation of stock authorized is to be completed before 30 November 2009 [Figure 1]. After this period, the rosewood from the region of SAVA and that of Analanjirofo may under no circumstances be exported", yet Note No. 218-PM-SP.09 of 31 December 2009 states the opposite: "From the date of signature of this note, operators who have already fulfilled conditions stipu- 
lated in the Interministerial Order before 30 November 2009 [Figure 1], in accordance with conditions determined by the Interministerial Order No. 38244 of 21 September 2009 [Figure 1] concerning the export of precious woods (inventories, approval, payment of royalties, taxes and fines ...), can proceed with the preparation and shipment of sending their containers of rosewood."

There are numerous other examples of such contradictions, starting with the constitution itself, which legislation and regulations have shamelessly violated for years:

- $\quad$ Preamble to the Constitution: "Recognizing the importance of the exceptional wealth and distinctive nature of the fauna, flora and mineral resources with which nature has endowed Madagascar and the importance of preserving it for future generations; $(. . .)^{\prime \prime}$; Article 39: "All persons have an obligation to respect cultural values, public property and the environment. The State and decentralised local authorities guarantee the preservation, protection and valorisation of the environment through appropriate measures."

It should be noted that respect for Madagascar's Constitution is only a formality at present, even though text continues to appear in the introduction to decrees and other official documents. A judge cannot reasonably be expected to condemn someone accused of an offense under the forestry law when the legal basis of the relevant texts is so pliable. Of the 23 exporters mentioned above, 13 have already been brought before a court on accusations of crimes related to forest exploitation, yet only two were convicted while the others were released, apparently due to lack of sufficient evidence.

The ruling elite: The weakness of Madagascar's central power and its poor governance have been highlighted by many authors. Roubaud (2001: 12 and 15) writes: "The disappointment of the public concerning the benefits of the transition is primarily motivated by the behaviour of newly-elected officials who see electoral competition as a way to harness public resources (the diversion of funds is one of many examples of this trend)", and "Contrary to accepted belief, the main obstacle to the development of Madagascar does not lie in the excesses of public regulation, but in its chronic poor administration. Malagasy democracy is ill - not the constituents, but the state and its elites".

Attention was drawn to the forestry sector by Mercier (2006), who described the application of forestry policy and regulations as being hampered by institutional weaknesses and serious problems in governance. More generally, an abundance of natural resources promotes corruption in countries where its institutions have a low level of democracy because it encourages leaders to favour sources of guaranteed income (Bhattacharyya and Holder 2009). Angeles and Neanidis (2009) evaluated the critical role of the local elite in effectively eliciting foreign aid in developing countries. There is a greater likelihood of misusing aid if the ruling class has significant economic and social power along with little regard for the lower classes, and if the ratio of European settlers to the indigenous population was high during the colonial period (Angeles and Neanidis 2009). Madagascar clearly suffers from some severe handicaps.

The GW and EIA (2009) report spells out examples of poor governance and corruption. According to a report by the Task Force (Rasoloson Fanomezana 2008 cited in GW and EIA 2009),
Minister Bernard Koto personally intervened on the part of the companies Bezokiny Christian Claude, Ste Thunam Roger et Cie, and Ets Ranjanoro, which led to uncomfortable situations for certain MEF officials. According to MEF's Director of Compliance and Integrity Improvement (DCAl), an officer of the Water and Forest Department was involved with each violation uncovered. Indeed, the temptation is great for a poorly-paid civil servant to benefit personally from his / her position's power to authorize access to forest natural resources, either for firewood or timber (Brinkerhoff 1996). Corruption runs through all government departments involved in rosewood: MEF, the Gendarmerie and Police, the Ministry of Justice, transporters, village chiefs, and mayors of urban centres. This is echoed in a 26 June 2007 World Bank report, which indicates that weak institutional capacity and poor governance diminished the commitment of the Government of Madagascar during the first half of the Environmental Program II (1998-2002). Logging permits were allocated, taking advantage of the fact that the boundaries of protected forests were as yet not geo-referenced nor delimited on the ground.

The activities of the MEF in January 2008 are worth careful scrutiny: Three notes were signed on the same day, 10 January 2008 (01-08/MEEFT/SG/DGEEF, 02 - 08 / MEEFT / SG / DGEEF / DRVN / SADG, and 03-08 / MEEFT / SG /DGEEF), cancelling all logging permits and authorizations for timber export. A few days later, on 29 January 2008, the same minister signed two additional notes, one of which set new requirements for obtaining export approval (note No. 086 / 08 / MEEFT / SG / DGEEF / DVRN) and another internal note (No. 005/08-MEEFT/Mi) stating that export licenses were still suspended. Seen from the perspective of operators, it appeared that the Minister Harison Randriarimanana was encouraging loggers to perpetrate acts of corruption to protect their investments, as their products were now subject to confiscation in Antalaha and thus in jeopardy since these ministerial notes were issued (Anonymous 2008b).

The proliferation and inconsistency of regulations in this arena during more than a decade effectively paralyzed justice and encouraged impunity on the part of unscrupulous exporters. We believe there is in fact an organized movement (collective, predetermined behaviour over several years) whose purpose is to stimulate and sustain the activities of the ruling elite. The response of exporters to the proliferation of memos in January 2008 seems to indicate that their preferred option was to try to reverse any decision not in their favour by means of corrupting the authorities. This was done by attempting to convince policy-makers based in the capital that their decisions were inappropriate and counter-productive, and that they encourage foreign competition. The unstable nature of the forestry regulations is the result of decisions made at the highest governmental levels, giving those holding power at the central and regional levels in each department the opportunity to negotiate and cut a deal. This applies, for example, to State responses to natural disasters, preparations for elections, improving the balance of payments, the prestige of personal influence and efforts to increase votes for a chosen candidate.

China and U.S. Lacey Act: The stringent measures implemented by the Chinese government to stop environmental disasters in its own country have had serious repercussions on the rest of the world. Since China banned logging in its own forests in 1998, imports of timber have increased six-fold, 
making it second only to Japan in purchases from countries with tropical rainforests. By actively protecting their own forests and thereby "exporting deforestation" (Liu and Diamond 2005), China and Japan are wreaking havoc in places such as Malaysia, Papua New Guinea, Australia, and now Madagascar.

Records of Chinese imports show that the main suppliers of rosewood in 2008 were Myanmar (41,000 tonnes) and Mozambique (27,000 tonnes) (James Hewitt In litt.). However, our sources are unsure that the rosewood reportedly exported by Mozambique in fact came from that country: Madagascar, located just across the narrow Mozambique Channel, exported around 36,000 tonnes in 2009. It is both interesting and important to note that Chinese customs records indicate only 1,000 tonnes of logs as originating from Madagascar in 2008, while the amount of rosewood exported from Madagascar that year reached almost 14,000 tonnes. China has always been the major buyer of Malagasy rosewood (e.g., $98 \%$ about a decade ago, Stasse 2002) and in 2009 almost $100 \%$ of exports were shipped there. As long as countries such as China use customs codes that do not allow transparency of imports and origins, it will remain almost impossible to track the rosewood trade accurately. In this regard, the United States has been exemplary in its implementation of the Lacey Act, which prohibits the import of illegally sourced timber. The aim of this act is to shift part of the responsibility to the US as an importing country rather than leaving it entirely in the hands of the exporting / source country.

The donors: Madagascar's unique and threatened biodiversity has, for more than two decades, made it a high priority for the international conservation and development community. Donors congregated in Madagascar in 1991 for a Multi-Donor Secretariat (MDS), representing the International Non-Governmental Organizations (INGOS) - Worldwide Fund for Nature (WWF), Conservation International (Cl), Wildlife Conservation Society (WCS) - and Agencies for Development of the countries concerned (France, Germany, Japan, Norway, Switzerland and USA), plus the United Nations and the World Bank. Over \$ US 320 million has been invested by members of this community. Yet the silence of the donors and INGOs during 2009, when efforts made over many decades to protect natural assets quickly collapsed, is puzzling. Where are the results of the massive financial aid they channelled into the country? When President Ravalomanana stepped down on 17 March 2009, the international community responded by immediately suspending all financial assistance, except some humanitarian aid. Lenders, donors and the INGOs suddenly found themselves deprived of any leverage, which proves that their influence was only financially driven - no more money means no more influence.

The Malagasy State depends on international assistance, and even more so for the funding of the National Environmental Action Plan, which relies on foreign funding for more than $80 \%$ (Rabesahala Horning 2008). The donor institutions and INGOs left the door wide open for the logging syndicate to lobby those in power and to do so successfully. Given the near-complete silence of the INGOs, there is growing international sentiment that the donors might not appreciate the lack of tangible results for their support and there is also concern that the INGOs actually have had a corrupt interest in minimizing the gravity of the forestry crisis in 2009, lest their funds dry up. According to Rabesahala Horning (2008), the local elite treat aid as an "annuity" - a "mass of money" that is automatically due to the country because of the "uniqueness of Madagascar's biodiversity on a global level".

IMPACTS. Impact on parks: For several months during 2009, thousands of people were involved in logging rosewood and ebony in the protected areas of the SAVA and Analanjirofo regions. The logged portions of the Masoala Park amount to approximately 4,000 hectares - less than $2 \%$ of its total area (230,000 hectares). But logging is not concentrated at one particular site, nor do these sites constitute small islands: they are selected according to two criteria: (1) Abundance of large rosewood trees (i.e., undisturbed forest below 400 m, Humbert 1965); and (2) ease of evacuating logs (i.e., proximity to a watercourse). Almost all lowland rainforest in valleys near Marojejy has thus been logged. Moreover, logging was not limited to Dalbergia trees: Five times as many lightweight trees (mostly Dombeya spp.) were felled in order to float the heavy rosewood (and ebony) logs, and innumerable lianas were cut to bind the logged trees to make rafts. Lianas play a key role in ecological interactions, especially in the tropics: $75 \%$ of rainforest fauna lives in the canopy (Hallé 2009) and lianas are needed by many species to move around the forest. Additional impacts resulted from the many tracks that were created to haul logs to the nearest rivers. Other trees of random species were felled to facilitate access to rosewood trees or to help transport the precious timber through very rough terrain. Temporary camps were established deep in the forests to accommodate several hundred loggers, dramatically increasing the need for firewood and bushmeat (in particular mammals and birds) and adversely affected the protected areas in the SAVA and Analanjirofo regions. A guide returning from a hike with a tourist and a student in Masoala on 18 July 2009 reported the presence of thousands of people actively logging in the park. Some were transporting trees, others stacking logs. These observers noted that the forest was almost stripped bare and wildlife had disappeared. A local resident confessed to poaching 26 lemurs in a two week period (Andriatahina and Rakotondrabe 2009).

According to Stasse (2002), a decade ago three tonnes of rosewood were easily felled in a day by a team of three to six loggers. By 2002, the same team were unable to find more than a single log per day, and in 2009, they were cutting trees as small as $10 \mathrm{~cm}$ in diameter, well before reaching reproductive maturity. Moreover, seedlings and young saplings are damaged or killed when harvested trees are felled and transported. Instead of being managed, the resource is being pillaged.

Peripheral damage from selective logging includes the loss of genetic diversity (Gillies et al. 1999, Brown and Gurevitch 2004), an increase in the risk of fire in cut areas (Cochrane and Schultze 1998, Cowlishaw and Dunbar 2000), destruction of habitat and the demise of wildlife (Ganzhorn et al. 1990), and a decrease in the number of endemic species (Irwin et al. 2010). Unfortunately, it is not possible yet to assess and quantify the full range of impacts caused by the intrusion of thousands of illegal loggers into the National Parks.

Socio-economical impact: The most significant economic consequence of the prolonged, selective logging in Madagascar has been a marked decrease in ecotourism during 2009. According to the National Tourism Office, the number of visitors declined $56 \%$ compared to the previous year (i.e., to just 162,687 arrivals, World Bank 2010), and income from tourism decreased from \$ US 465 million to \$ US 180 million. Madagascar's tourism 
industry annually brings nearly a half-billion US dollars to tens of thousands of people involved in all aspects of the industry (hotel and restaurant staff, guides, drivers, taxi operators, boat skippers, artisans and more). By contrast, the illegal high-end timber industry has resulted in a one-time windfall of an estimated \$ US 220 million (Table 2) for just twenty-three individuals and a smattering of minor payments to a limited number of other players involved.

As the eco-tourism industry continues to decline in tandem with the degradation of the forests and of security, the very image of Madagascar itself has been severely tarnished. Those with some common sense have just cause for alarm: More than just logs of rare timber are leaving the country - jobs, livelihoods and reputations are at stake. On several occasions over the past decade, the government has banned the export of unprocessed precious wood (i.e., in the form of logs). According to Global Witness (GW and EIA 2009), a large rosewood cabinet sells in China for between $\$$ US 18,700 and $\$$ US 25,000 , and a Chinese importer would pay \$ US 750 to 1,000 for the raw material bought from exporters in Madagascar. If a Chinese consumer spends \$ US 25,000 on a cabinet, then his compatriots involved in processing, distribution and importing retain \$ US 24,000, compared with the $\$$ US 1,000 that accrues to the Malagasy sellers (Table 1). The Chinese interests involved in the industry are thus earning nearly 25 times more than their Malagasy suppliers, and 357 times more than the villagers working in Malagasy forests, who earn around \$ US 67 (Table 1).

Vast sums of money are required to remove large amounts of rosewood and ebony from remote forests and transport them to stored sites until the administrative situation is favourable (which can take years), and then exporting the wood involves paying heavy taxes (Table 1). Most exporters simply do not have the necessary funds themselves, so they resort to ingenious ways to circumvent making payments or to reduce the amounts they have to pay. For example, some exporters have diverted funds provided by the BOA that should have benefitted the vanilla industry, and it is thus hardly surprising that the price of Malagasy vanilla was particularly low in 2009. This is not just a consequence of the law of supply and demand nor the minimum prices set by Ministers ( $\$$ US 27 per kilogram in 2009), but rather a lack of motivation on the part of farmers to produce good quality vanilla in sufficient quantities. If the exporters of rosewood - most of whom also export vanilla - tell producers that they will buy little or no vanilla in a particular year, thereby making farmers aware of an impending plunge in the price of vanilla, the farmers will naturally go into the forests to cut rosewood, because they know there will be firm orders and guaranteed prices that are far more attractive. This is precisely how the timber exporters corralled their workforce: Through economic coercion they deliberately forced people who would ordinarily have been involved in the vanilla industry into the illicit rosewood industry.

Another noticeable consequence of illegal rosewood exploitation has been the closure of schools in remote villages, particularly around Marojejy National Park. This results directly from the economic ills suffered by the local communities, principally because of the low (fixed) price of vanilla, which has made it impossible for villagers to afford school fees or pay teachers salaries. So the schools are closed, at least temporarily, and the children are sent to work the rice fields because they must eat every day. A new generation of woodcutters thus grows up lacking education, ignorant of the world around them.

\section{CONCLUSION}

For more than ten years, Madagascar's rosewood industry has followed what has now become a regular cycle:

1. Under the influence of environmental donors (who must demonstrate visible results during the lifetime of their projects), the government enacts sound forestry legislation and takes restrictive regulatory measures, but it does this without having the capacity, human OR moral, to apply them;

2. Since export of precious timber is illegal, rosewood loggers accumulate stocks, either discretely or overtly, as is currently the case in Vohemar and Antalaha, where there are numerous rosewood caches. The law is publicly disregarded, officials charged with its application are disoriented, and the authority of the State is weakened;

3. Taking advantage of an external event such as a cyclone, an election, or a difficult political transition, lobbying by the logging syndicate is heard and acted upon by the governing class, which then issues a series of orders authorising the exceptional one-time export of the stockpiled wood (examples: 2000, 2004, $2005,2007,2009)$, apparently without the possibility of later exemption (although we note that the number of examples clearly illustrates many exemptions);

4. Logging companies export massively, attempting, often with success, to involve members of the governing class in their business;

5. Once the donors raise their voices, there is a (temporary) return to Phase 1.

It is important to note that illegal exploitation continues throughout the entire cycle, as the government only really controls the export process (i.e., from the loading of containers on board a ship in port to its departure). Timber exporters accumulate stocks while waiting for a favourable phase in the cycle, a process that will almost surely continue until the resource is totally depleted. For some, the forest is a refuge of unique biodiversity, while for others it is simply an adjustable budgetary variable. And for others still, it is a source of personal enrichment.

\section{ACKNOWLEDGEMENTS}

We express our warm gratitude to all those who provided information on export of the varied aspects of the rosewood trade. They include businessmen, politicians, officials of MEF, customs and port officials, judges, journalists, agents of Madagascar National Parks, tourist guides, artists, bankers, radio hosts, hotel employees, truck drivers, lumberjacks, collectors and exporters. Many have taken great risk to speak with us, some have been threatened with death, another had his house burned, and one had his foot crushed. Without these peoples' courage to speak out, we would not have been able to write a line of this article. The people of Madagascar will never really know how indebted it is to the many anonymous and unsung heroes.

We applaud the Missouri Botanical Garden (St. Louis, USA) who, through personal commitment of its president, Peter Raven, and his collaborators, was the first foreign institution 
- and unfortunately the only one - to have demonstrated the courage to publicly denounce the situation in Madagascar at the World Forestry Congress in Buenos Aires in October 2009 and the UN Climate Change Conference in Copenhagen later that year. It has indeed been thanks to the work of this institution that the media began to give exposure to the crisis surrounding Madagascar's rosewood.

Finally, we express our gratitude to the four anonymous reviewers who spent considerable time improving this study.

\section{REFERENCES}

Anonymous. 2008a. Filière bois de rose: entre mythe et réalité. Madagasikara Soa 04-02-2008. <http://www.madagasikara-soa.com/ index.php/Chroniques-politiques/Filiere-Bois-de-rose-Entre-mythe-etrealite.html> accessed 18 November 2009 .

Anonymous. 2008b. Le ministre se contredit. Madagascar Tribune 9 février 2008. <http://www.madagascar-tribune.com/Le-ministre-se-contredit,4682.html> downloaded 18 November 2009.

Anonymous. 2009. Affaire bois de rose: des opérateurs s'insurgent. Courrier de Madagascar 2109. <http://www.courriermada.com/spip. php? page=article_pdf\&id_article=2109> accessed 28 October 2009

African Elections Database. 2010. Elections in Madagascar. <http://africanelections.tripod.com/mg.html> accessed 18 February 2010

Andriatahina, M. \& Rakotondrabe, B. 2009. Rapport de Mission en SAVA du 19 au 22 juillet 2009. Unpubl. report to ONESF.

Angeles, L. and Neanidis, K. C. 2009. Aid effectiveness: The role of the local elite. Journal of Development Economics 90, 1: 120-134. (doi:10.1016/ j.jdeveco.2008.05.002)

Ballet, J. \& Rahaga, N. 2009. Impact Économique des Arrêtés Autorisant les Exportations de Bois Précieux à Madagascar. Unpublished report to PGM-E/GTZ.

Bhattacharyya, S. and Hodler, R. 2009. Natural resources, democracy and corruption. European Economic Review. Department of Economics. Working Papers Series 1047, The University of Melbourne, Melbourne.

Birkinshaw, C. and Randrianjanahary, M., 2007. The effects of cyclone Hudah on the forest of Masoala Peninsula, Madagascar. Madagascar Conservation \& Development 2, 1: 17-20.

Botokely (Marc Clique). 1902. Chronique commerciale, industrielle et agricole. Revue de Madagascar 4, 4: 356-365

Brinkerhoff, D. W. 1996. Coordination Issues in Policy Implementation Networks: An Illustration from Madagascar's Environmental Action Plan. World Development 24, 9: 1497-1510.

Brodbeck, F. 1999. La Filière Bois dans les Régions de Antsinanana et Toamasina (Description, Analyse et Comparaison). Unpubl. Master Theses.

Brown, K.A. and Gurevitch, J. 2004. Long-term impacts of logging on forest diversity in Madagascar. Proceedings of the National Academy of Sciences of the United States of America 99, 4: 2067-2071. (doi:10.1073 pnas.0401456101)

Canby, K., Hewitt, J., Bailey, L., Katsigris, E. and Xiufang, S. 2008. Forest Products Trade between China and Africa: An Analysis of Imports and Exports. Forest Trends, Washington D. C. \& Global Timber, London. <http://www.forest-trends.org/publication_details. php?publicationID=515> accessed 18 November 2009 .

Cochrane M. A. and Schulze M. D. 1998. Forest fires in the Brazilian Amazon. Conservation Biology 12, 5: 948-950. (doi:10.1046/j.15231739.1998.012005948.x)

Cowlishaw, G. and Dunbar, R. 2000. Primate Conservation Biology. The of Chicago Press, Chicago

Débois, R. 2009. La fièvre de l'or rouge saigne la forêt malgache. Univers Maoré 13: 8-15.

Ganzhorn, J. U., Ganzhorn, A. W., Abraham, J.-P., Andriamanarivo, L. and Ramananjatovo, A. 1990. The impact of selective logging on forest structure and tenrec populations in western Madagascar. Oecologia 84, 1: 126-133

Gillies, A. C. M., Navarro, C., Lowe, A. J., Newton, A. C., Hernández, M., Wilson, J. and Cornelius, J. P. 1999. Genetic diversity in Mesoamerican populations of mahogany (Swietenia macrophylla), assessed using RAPDS. Heredity 83: 722-732.
GW and EIA. 2009. Investigation into the illegal felling, transport and export of precious wood in SAVA Region Madagascar. Unpublished report to the Government of Madagascar. <http://www.illegal-logging.info/ uploads/madagascarreportrevisedfinalen.pdf> accessed 26 November 2009.

Hallé, F. 2009. Requiem pour les forêts tropicales, Univers Maoré 9 : 10-21.

Humbert, H. 1965. Description des types de végétation. In: Notice de la carte de Madagascar. H. Humbert et G. Cours Darne (eds.), pp 46-78. Travaux de la Section Scientifique et Technique de l'Institut Français de Pondichéry Hors série 6 .

Irwin, M. T., Wright, P. C., Birkinshaw, C., Fisher, B. L., Gardner, C. J., Glos, J., Goodman, S. M., Loiselle, P., Rabeson, P., Raharison, J.-L., Raherilalao, M.-J., Rakotondravony, D., Raselimanana, A., Ratsimbazafy, J., Sparks, J. S., Wilmé, L. and Ganzhorn, J. U. 2010. Patterns of species change in anthropogenically disturbed forests of Madagascar. Biological Conservation In Press. (doi:10.1016/j.biocon.2010.01.023)

Liu, J. and Diamond, J. 2005. China's environment in a globalizing world, How China and the rest of the world affect each other. Nature 435: 1179-1186. (doi:10.1038/4351179a)

Maka, A. 2009. Elections législatives pour le 20 mars 2010 - « C'est faisable ! ». La Vérité 18 décembre 2009. <http://www.laverite.mg/actualites-a-madagascar/elections-legislatives-pour-le-20-mars-2010-Icestfaisabler.html> accessed 18 December 2009.

Mercier, J.-R. 2006. The preparation of the National Environmental Action Plan (NEAP): Was it a false start? Madagascar Conservation \& Development 1, 1: 50-54.

Missouri Botanical Garden. 2009. Rapport Préliminaire sur I'Analyse Écologique et Économique des Bois Importants dans le complexe Forestier de Makirovana - Tsihomanaomby. Unpubl. report to World Wide Fund for Nature (WWF) \& Département de Biologie et Écologie Végétale (DBEV) de I'Université d'Antananarivo.

Naidu, S. \& Mbazima, D. 2008. China-African relations: A new impulse in a changing continental landscape. Futures 40: 748-761. (doi:10.1016/ j.futures.2008.02.007)

Parant, B., Chichignoud, M. et Rakotovao, G. 1985. Présentation graphique des caractères technologiques des principaux bois tropicaux. Tome 5 . Bois de Madagascar. CIRAD, Montpellier.

Rabesahala Horning, N. 2008. Strong support for weak performance donor competition in Madagascar. African Affairs 107, $428:$ 405-431. (doi:10.1093/afraf/adn036)

Roubaud, F. 2001. Démocratie électorale et inertie institutionnelle à Madagascar. Unpublished report to Développement et Insertion Internationale. <http://www.dial.prd.fr/dial_publications/PDF/Doc_travail/2001-03.pdf> accessed 15 December 2009

Service de la Météorologie 2000. Perturbations cycloniques à Madagascar de 1961 à 2000. Unpubl. report. (Also <http://www.reunion.sit.gouv. $\mathrm{fr} /$ statique/pp/meteo.html>; $<$ http://www.meteolafleche.com/Cyclone/ Gafilo/gafilo.html>; <http://firinga.free.fr/Archives/indlala_07.html> accessed 18 November 2009.

Stasse, A. 2002. La Filière Bois de Rose. Région d'Antalaha - Nord-est de Madagascar. Thèse de mastère non publiée, Université de Montpellier, France.

World Bank. 2010. Madagascar - Economic update : 2009 and beyond. $<$ http://blogs.worldbank.org/files/africacan/MADAGASCAR\%20update \%20feb\%201\%202010.pdf> accessed 04 February 2010.

World Meteorological Organization. 2008. Tropical Cyclone Programme. Report No. TCP-23. Secretariat of the World Meteorological Organization, Geneva. <http://www.wmo.ch/pages/prog/www/tcp/ documents/TCP-23EDITION2008.pdf>

\section{SUPPLEMENTARY MATERIAL.}

AVAILABLE ONLINE ONLY.

Report entitled 'Bois de rose de Madagascar : Entre démocratie et protection de la nature.' Prepared by Hery Randriamalala et Zhou Liu, 01 March 2010, 59 pp. 